\title{
Characterization of Pregnancy-Associated Glycoprotein as a Biomarker of Pregnancy in Etawa Crossbred Goat
}

\author{
Intan Kumala Ningtyas ${ }^{1,2^{*}}$, Tita Damayanti Lestari ${ }^{1}$ and Herry Agoes Hermadi ${ }^{1}$ \\ ${ }^{I}$ Department of Veterinary Reproduction, Faculty of Veterinary Medicine, Airlangga University, Surabaya, East Java 60115, Indonesia \\ ${ }^{2}$ Biosains Institute, Brawijaya University, Malang, East Java 65145, Indonesia \\ *Corresponding author ${ }^{\text {'s }}$ Email: intankumala01@ gmail.com ; ORCID: 0000-0003-4894-5575
}

\begin{abstract}
Pregnancy-Associated Glycoprotein (PAG) is secreted by the placenta, which is produced in mononucleate and binucleate trophoblast cells. The current research was conducted to find out a substance for diagnosing early pregnancy in Etawa crossbred goats. Six Etawa crossbred goats (not pregnant, three months pregnant and four months pregnant) were subjected in the present study from Livestock Government Institution Breeding in Singosari, Malang. The research methods consisted of sample collection, identification PAG with sodium dodecyl sulfatepolyacrylamide gel electrophoresis, the determination of concentration with Biuret method and specificity test with Western Blot assay. The obtained results showed that the molecular weight of PAG from pregnant Etawa crossbred goats was $55.85 \mathrm{kDa}$. The average concentrations of PAG in the goats of non-pregnant, three months pregnant, and four months pregnant were $1.83 \pm 2.98,3.79 \pm 2.72$ and $4.36 \pm 2.63$, respectively. The results of the specificity test with the Western Blot molecular revealed a molecular mass of PAG was $55 \mathrm{kDa}$. The findings of the present study demonstrated PAG in Etawa crossbred goats can be used as an indicator of pregnancy.
\end{abstract}

Key words: Biomarkers, Etawa crossbred, PAG, Pregnancy

\section{INTRODUCTION}

Diagnosis of early pregnancy in goat can be done in two ways: through detection of specific substances in the peripheral circulation such as Pregnancy-Associated Glycoprotein (PAG) or non-specific substances in the blood, urine or milk such as progesterone and estrone sulfate (Hafez, 2000). PAGs are pregnancy indicators that are produced by mononucleate and binucleate trophoblastic cells (Perenyi et al., 2002; Karen et al., 2003; Sousa et al., 2006). Garbayo et al. (1998) purified three PAGs from goat placenta which differed in amino acid sequences and molecular weight (55 $\mathrm{kDa}, 59 \mathrm{kDa}$, and $62 \mathrm{kDa}$ ) and each of them had several isoforms with different isoelectric points. Isolation of ovine PAG was obtained at a molecular weight of $30.86 \mathrm{kDa}$ from placental cotyledon (Setiatin et al., 2009). In cattle, PAG isolated from the blood serum during 274-279 days of gestation was characterized in molecular weight of $67.34 \mathrm{kDa}$ (Lestari and Ismudiono, 2011). In livestock reproductive management, early pregnancy diagnosis is very economically advantageous in determining pregnancy status after mating (Restall et al., 1990; Goel and Agrawal, 1992). Generally, the length of the estrous cycle of the goat is around 21 days (Jainudeen et al., 2000). The economic losses of pregnant goats can be minimized or prevented by methods of early pregnancy diagnosis (Singh et al., 2004).

Pregnancy tests have the potential to be very suitable for field practice. PAG can be measured in maternal blood circulation (Shahin et al., 2013). Pregnancy is diagnosed using PAG test on day 24 of gestation (Reese et al., 2017). The knowledge of mechanisms involved in the production and control of PAG is beneficial in livestock breeding and facilitates diagnosis of pregnancy (Santos et al., 2018). Therefore, the current study was designed to evaluate blood serums for early pregnancy diagnosis in Etawa crossbred goats managed in intensive conditions in Indonesia.

\section{MATERIALS AND METHODS}

\section{Ethical approval}

This study was approved by the Institutional Animal Ethics Committee Brawijaya University (Code No.1108-KEPUB).

\section{Collection of Samples}

The present study was conducted on six crossbred goat aged 3 to 4 years in Livestock Breeding Institution Government in Singosari, Malang, East Java, Indonesia. The analysis of blood samples was conducted at the Department of Veterinary Reproduction Airlangga University, Surabaya and Biosains Laboratory, Brawijaya University, Malang, 
East Java, Indonesia. The goats were maintained under intensive system of management in well-ventilated pens and dietary and management conditions were the same for animals. Blood samples were taken from jugular veins of nonpregnant and pregnant goats in the different gestational age (3-4 month). The serum samples were centrifuged at 3000 rpm for 10 minutes and the supernatant was transferred in a new tube and was stored at $-20^{\circ} \mathrm{C}$ until further use.

\section{Identification of PAGs with Sodium Dodecyl Sulfate-Polyacrylamide Gel Electrophoresis (SDS-PAGE)}

The running gel was inserted into the SDS-PAGE tool through the wall to below the top line. Then, $1 \mathrm{ml}$ butanol was added and left for 25 minutes. After the gel freeze, butanol was removed and cleaned with PBS then dried with Whatman paper. The $12 \%$ stacking gel is inserted from the top of the wall until it was fully set for 25 minutes. The comb was inserted and the remaining gel was cleared with a buffer. The samples were mixed with $5 \mu 1$ of liquid buffer and heated at $100^{\circ} \mathrm{C}$ for 5 minutes. Then samples were inserted into the mold hole with a tip of $200 \mu$ l. The mold is inserted into an electrophoresis gel device, the power supply at the start was $125 \mathrm{~V}, 40 \mathrm{~mA}$ for one hour. When the electrophoresis was completed, it was turned off and the plate was opened and separated, then the gel was stained with Coomassie Brilliant Blue (Merck, Germany). Molecular weight determined using standardized regression between relative migration and molecular weight markers. Then, it was tested for specificity with Western Blots test.

\section{Examination of PAGs levels using the Biuret method}

The not-colored SDS-PAGE gel was cut to the desired tape. Each gel was inserted into a nylon sack and packed in a glass block containing PBS while were mixed on a magnetic stirrer for 24 hours. PBS was replaced every 6 hours. The gel pieces were stained with silver staining to detect protein. The total protein concentration was determined using Biuret reagent by adding a standard solution of Bovine Serum Albumin (BSA) protein. The sample cuvette was prepared with a PAG and $2.5 \mathrm{ml}$ of the Biuret reagent. The standard cuvette as filled with $0.05 \mathrm{ml} \mathrm{BSA}$ and $2.5 \mathrm{ml}$ of the Biuret reagent. The blank cuvette was prepared by adding $2.5 \mathrm{ml}$ Biuret reagent and $0.05 \mathrm{ml}$ of distilled water. Three cuvettes were left for 30 minutes and color intensity was read by Bausch Lomb Spectronic Spectrophotometer at a wavelength of $540 \mathrm{~nm}$.

\section{Specificity test of PAG with Western Blot}

Western blot was carried out by using fragments of PAG bands which had been run in SDS-PAGE and were transferred to the nitrocellulose membrane. The membrane was blocked with $3 \% \mathrm{BSA}$ in $20 \mathrm{mM}$ Tris- $\mathrm{HCl}$ at $\mathrm{pH} 7.5$ and $150 \mathrm{mM} \mathrm{NaCl}$ for one hour then was incubated with the primary antibody (anti-PAG) diluted in Tris/ $\mathrm{NaCl}$ containing $1 \%$ BSA. After washing with Tris-Cl containing 0.05\% TWEEN 20, the membrane was incubated with secondary antibodies (anti-rabbit IgG labeled AP, 1:1000 dilution) and was added Western Blue Substrate (Promega, USA) (Aulanni'am, 2004).

\section{Statistical analysis}

The standard protein curve was made to obtain the molecular relative mass of the samples (Gaspersz, 1995). The relative molecular mass of each protein defined by data converted from relative migration distance $(R f)$ values according to following linear equation: $\mathrm{Y}=\mathrm{b} 0+\mathrm{b} 1 \mathrm{X}$; where $\mathrm{Y}$ is molecular weight $(\mathrm{kDa}), \mathrm{b} 0$ is a constant, b1 is coefficient of relative migration, and $\mathrm{X}$ is relative migration of protein band.

The total protein concentration of PAGs by Biuret method was calculated as follows: $\mathrm{Y}=5.10^{-5} \mathrm{X}$ Where $\mathrm{Y}$ is absorbance and $X$ is a concentration of protein $(\mu \mathrm{g} / \mathrm{ml})$. The data of the Biuret method was statistically analyzed using ANOVA multivariate. Data were analyzed using SPSS version. 17.0 software (SPSS Inc, USA). A p <0.05 were regarded as statistically significant.

\section{RESULTS}

The profile of the PAGs isolated from blood serum of Etawa crossbred goats using SDS-PAGE are shown in figure 1. The protein molecular weight was measured by relative migration when the protein passes through the separating gel (Figure 2). Then, based on the logarithmic equation $(y=2.401+-1.4752 X ; \mathrm{R} 2=0.9829)$ obtained by calculating the relative migration, the molecular weight was obtained as a band that appeared on electrophoresis. The molecular weight of protein bands from six samples are presented in table 1. The serum of control and pregnant goats has the same protein profile. However, in blood serums of pregnant goats, there was a protein with a molecular weight of $55.85 \mathrm{kDa}$ which was expected to be a specific PAG.

To ensure that the electroelution protein was a PAG, the elution results was examined by Biuret method to determine PAG protein levels. The results of the examination using the Biuret method can be seen as isolation of PAG in table 2 . The protein concentration was the lowest in non-pregnant goats (1.83 \pm 2.98$)$, then 3 months pregnant (3.79 \pm 2.72$)$ and showed the highest value in 4 months pregnant $(4.36 \pm 2.63)$. The indicated correlation in blood serum had a significant difference $(\mathrm{P}<0.05)$. 
Specificity tests were carried out to ensure that the detected protein was PAG. The results of the Western Blot test showed purplish bands on nitrocellulose membranes with a molecular weight of $55 \mathrm{kDa}$ (Figure 3). This finding proved that the visible bands were PAG molecules. The molecular weight can be read using a reference marker protein with a molecular weight range of 15 to $260 \mathrm{kDa}$. Protein band with a molecular weight of $55 \mathrm{kDa}$ was found in samples of pregnant goats in gestational age 3 and 4 months, whereas in samples of non-pregnant goats there was a protein band with a molecular weight of $23 \mathrm{kDa}$.

Table 1. Molecular weight of protein obtained from blood serum of Etawa crossbred goats

\begin{tabular}{|c|c|c|c|c|c|c|c|c|c|c|c|c|}
\hline \multirow{2}{*}{$\begin{array}{l}\text { Serum } \\
\text { Sample }\end{array}$} & \multicolumn{12}{|c|}{ Protein Molecular Weight (kDa) } \\
\hline & 15.29 & 20.23 & 24.10 & 31.89 & 39.35 & 48.55 & 55.85 & 62.04 & 82.10 & 120.68 & 165.39 & 197.03 \\
\hline $\begin{array}{l}\text { Non- } \\
\text { pregnant }\end{array}$ & + & + & + & + & + & + & - & + & + & + & + & + \\
\hline $\begin{array}{l}3 \text { month } \\
\text { pregnant }\end{array}$ & + & + & + & + & + & + & + & + & + & + & + & + \\
\hline $\begin{array}{l}4 \text { month } \\
\text { pregnant }\end{array}$ & + & + & + & + & + & + & + & + & + & + & + & + \\
\hline
\end{tabular}

Table 2. The average concentration of PAGs isolated from blood serum of pregnant Etawa crossbred goats by using Biuret method

\begin{tabular}{ccccc}
\hline No. & Sample & Absorbance 1 & Absorbance 2 & $\begin{array}{c}\text { Average concentration } \\
(\boldsymbol{\mu g} / \mathbf{m l})\end{array}$ \\
\hline 1 & non-pregnant & 1.48 & 2.18 & ${ }^{\mathrm{a}} 1.83 \pm 2.98$ \\
2 & 3 month & 5.22 & 2.36 & ${ }^{\mathrm{b}} 3.79 \pm 2.72$ \\
3 & 4 month & 2.45 & 6.23 & ${ }^{\mathrm{c}} 4.36 \pm 2.63$ \\
\hline
\end{tabular}

Different superscript letters indicate significant differences ( $\mathrm{p}<0.05$ ); PAG: Pregnancy-Associated Glycoproteins; Absorbance was read in a spectrophotometer at a wavelength of $540 \mathrm{~nm}$

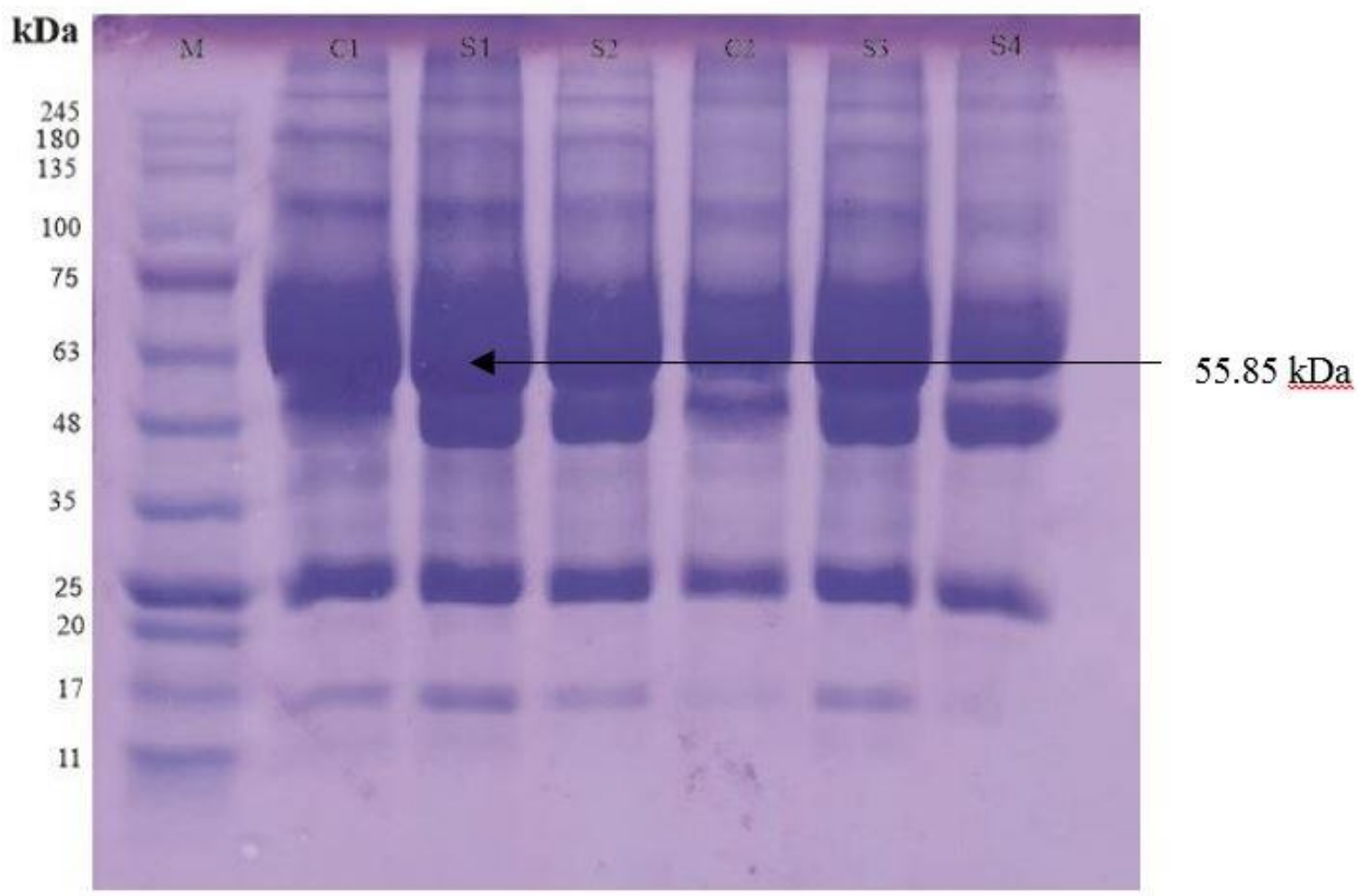

Figure 1. This is the SDS-PAGE analysis of PAGs isolated from blood serum of Etawa crossbred goats. Lane M: TrisGlycine 4-20\%, 11-245 kDa as marker; Lane C1 and C2: non-pregnant; Lane S1 and S3: 3 months pregnant; Lane S2 and S4: 4 months pregnant. 


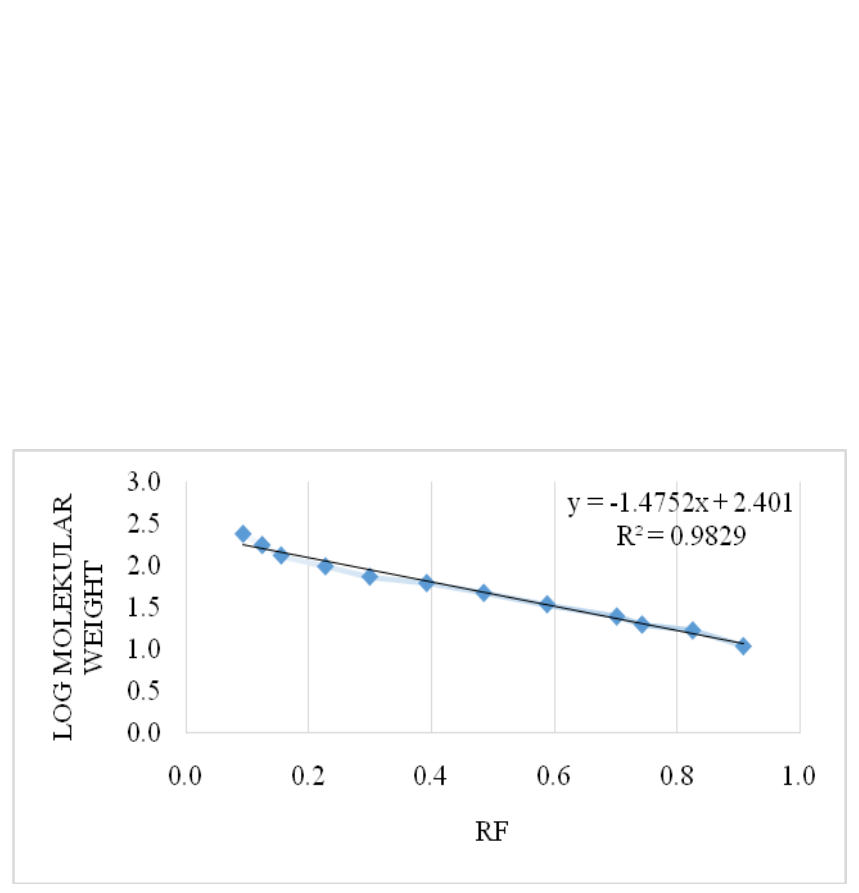

Figure 2. Determination of molecular weight by calculating the relative migration

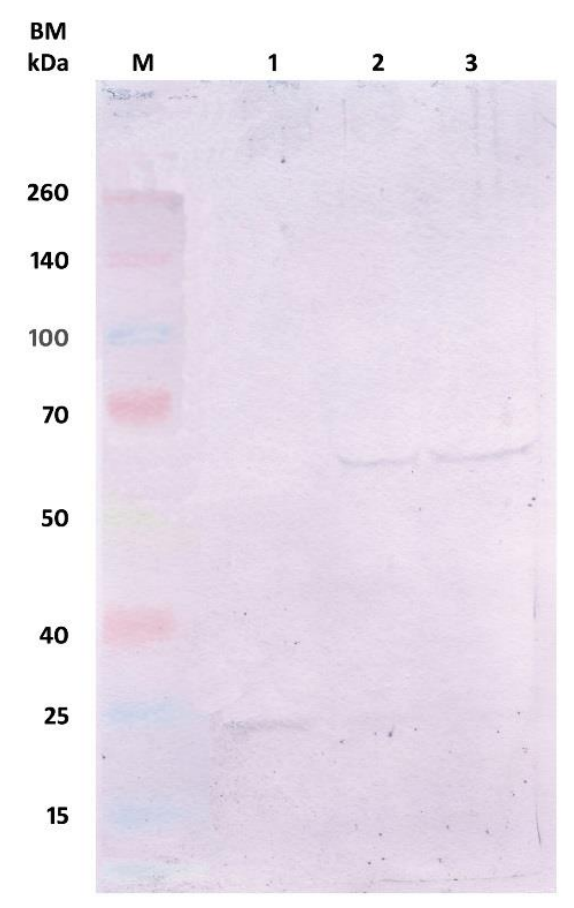

Figure 3. The Western Blot analysis for PAG isolated from blood serum of Etawa crossbred goats. Lane M: marker; Lane 1: non-pregnant; Lane 2: 3 months pregnant; Lane 3: 4 months pregnant.

\section{DISCUSSION}

According to the obtained results in the present investigation, the molecular weight of PAG in Etawa crossbred goats was $55.85 \mathrm{kDa}$. This finding is in accordance with the discovery of caprine PAG in the previous study by Amiri et al., (2004) that identification protein was performed by SDS-PAGE and found the molecular weight of caprine PAG was between 55 to $66 \mathrm{kDa}$. Moreover, Garbayo et al. (1998) reported different molecular mass (55 kDa, $59 \mathrm{kDa}$, and $62 \mathrm{kDa})$ for caprine PAG. PAGs can be detected in the maternal blood circulation from embryo implantation (Gordon, 1999). Trophoblast placental cells are present in blood circulation during implantation until parturition and are responsible for producing PAGs throughout the gestation period (Gonzales et al., 2000).

The protein concentration of PAG increases progressively at 3 and 4 months of gestation. Blood PAG levels steadily increased during early pregnancy in goats (Singh et al., 2019). Ispierto et al., (2016) reported PAG concentrations were significantly higher in twins compared to single pregnancies. The current research is in agreement with one of the statements by Cavanagh (1996) who mentioned PAG was first discovered as a substance-related to pregnancy and was detectable in 6-24 hours after conception in all species such as rats, humans, pigs, and sheep. Duplants (2000) declared that PAG was detected after the implantation and remained in the pregnant goat until parturition and disappeared after the birth process. Many factors influence the concentration of PAG, such as breeding (Ranilla et al., 1994; Guilbault et al., 1991), the number of fetuses (Benitez-Ortiz, 1992) and in vitro culture period (Ectors et al., 1996). Therefore, differences in PAG expression observed in the present study can be related to variations in breeds, procedures, and geographical location.

The results of present study showed the protein bands on nitrocellulose membranes, indicating a specific bond between PAG antibodies and PAG antigens isolated from Etawa crossbred goats pregnant. The further production of PAG increases the bond between PAG antibodies and PAG antigens and provides thicker protein bands. This finding is supported by Aulanni'am (2004), in Western Blot method, PAG antibodies recognize PAG antigens as specific antigens and bind together thus purplish-colored protein bands become visible.

\section{CONCLUSION}

The present study characterized PAG with a molecular weight of $55.85 \mathrm{kDa}$ in Etawa crossbred goats at 3 and 4 months before parturition. Moreover, application of PAG as a biomarker of pregnancy was confirmed in Etawa crossbred goats. 


\section{DECLARATIONS}

\section{Acknowledgments}

All authors are very grateful to Prof. Dr. Aulanni'am, DVM, DES for this research. The authors also thankful to laboratory assistant, veterinarian, and staff of Department Veterinary Reproduction Airlangga University and Biosains institute.

\section{Consent to publish}

All authors contributed to write and publish manuscripts in the World's Veterinary Journal.

\section{Competing interests}

The authors declare that they have no competing interests.

\section{Author's contribution}

IKN wrote the manuscript and conducted the research, TDL conceptualized the research, and HAP revised the final form of the manuscript.

\section{REFERENCES}

Aulanni'am A (2004). Principles and Techniques of Biomolecular Analysis. Brawijaya University Press. Malang. pp. 68-84.

Benitez-Ortiz W (1992). Diagnostic de gestation et e Âtude de la mortaliteÂembryonnaire chez les ruminants par dosage de la pregnancy associated glycoprotein (PAG), Ph.D thesis, Institute de MeÂdecine TropicalePrince LeÂopold, Antwerp. Global Veterinaria, 6: 346-351.

Cavanagh AC (1996). Identification of early pregnancy factor as Chaperonin 10: Implication for understanding its role. Journal Reproduction and Fertilization, 1: 28-32. DOI:https://10.1530/ror.0.0010028

DuPlants LJ (2000). Early Pregnancy Factor. Lifeissues.net. Kochi, Japan. All Rights Reserved. pp. 1-2.

Ectors FJ, Schmidt M, Sulon J, Deval A, Remy B, Avery B and Beckers JF (1996). bPAG profiles in recipient heifers after of IVF and nuclear transfer embryos. Theriogenology, 45: 283.

El Amiri B, Remy B, Sousa NM and Beckers JF (2004). Isolation and characterization of eight pregnancy-associated glycoproteins present at high levels in the ovine placenta between day 60 and day 100 of gestation. Journal of Reproduction, Nutrition, and Development, 44: 169-181. DOI:https://10.1051/rnd:2004025

Hafez ES (2000). Reproduction in Farm Animals, 7th Edition. Lippincott Williams and Wilkins, Philadelphia. pp. 157-189.

Ispierto IG, Rossello-Visa MA, Perez BS, Novales RM, Sousa NM, Beckers JF and Gatius FL (2016). Plasma concentration of pregnancy-associated glycoproteins I and II and progesterone on day 28 post-AI as markers of twin pregnancy in dairy cattle. Livestock Science, 192: 44-47. DOI:https://10.1016/j.livsci.2016.09.003

Garbayo JM, Remy B, Alabart JL, Folch J, Wattiez R, Falmagne P and Beckers JF (1998). Isolation and partial characterization of a pregnancy-associated glycoprotein family from the goat placenta. Journal of Biology Reproduction, 58: 109-115. DOI:https://10.1095/biolreprod58.1.109

Gaspersz V (1995). Analysis Techniques in Experimental Research, 1th Edition. Tarsito Publisher, Bandung. pp. 68-79.

Goel AK and Agrawal KP (1992). A Review of pregnancy diagnosis techniques in sheep and goats. Small Ruminant Research, 9:255264. DOI:https://10.1016/0921-4488(92)90155-W

Gonzales F, Sulon j, Garbayo JM, Batista M, Cabrera F, Calero A, Gracia A and Beckers JF (2000). Secretory profile of pregnancyassociated glycoprotein at different stage of pregnancy in the goat. Reproduction in Domestic Animals. 35: 79-81. DOI:https://10.1046/j.1439-0531.2000.00202.x

Gordon I (2004). Reproductive Technologies in Farm Animals. CABI Publishing. Cambridge. USA. pp. 256-262.

Guilbault LA, Beckers JF, Lapierre S, Zoli AP, Benitez-Ortiz W and Roy GL (1991). Peripartum concentration of placental protein hormones (bPL and bPAG) in Holstein and Hereford recipients carrying pubered Holstein foetuses. Theriogenology, 35: 208213. DOI:https://10.1016/0093-691X(91)90184-F

Jainudeen MR, Wahid H and Hafez ESE (2000). Sheep and Goats. In: Hafez B and E.S.E. Hafez (Editors.) Reproduction in Farm Animals. Lippincott Williams and Wilkins, Philadelphia, USA, pp. 172-181.

Karen A, Beckers JF, Sulon J, El Amiri B, Szabados K, Ismail S, Reiczigel J and Szenci O (2003). Evaluation of false transrectal ultrasonographic pregnancy diagnoses in sheep by measuring the plasma level of pregnancy-associated glycoproteins. Reproduction Nutrition Development, 43: 577-586. DOI:https://10.1051/rnd:2004005

Lestari TD and Ismundiono I (2011). Profile of blastocyst protein: pregnancy-associated glycoprotein (PAG) as an indicator of pregnancy in livestock. Journal of Reproduction, 54: 119-121.

Perenyi ZS, Desbuleux H, Sulon J, Szenci O, Banga-Mboko H, Sousa NM, El Amiri B and Beckers JF (2002). The ability of three different antisera to recognize pregnancy-associated glycoproteins in heifer during the first fifty days of gestation. Faculty of Veterinary Medicine, Liege University, Belgium.

Ranilla M.J, Sulon J, Carro MD, MantecoÂn AR and Beckers JF (1994). Plasmatic profiles of pregnancy-associated glycoprotein and progesterone levels during gestation in churra and merino sheep. Theriogenology, 42: 537-545. DOI:https://10.1016/0093691X(94)90691-B 
Reese ST, Pereira MH, Edwards JL, Vasconcelos JL and Pohler KG (2017). Pregnancy diagnosis in cattle using pregnancy associated glycoprotein concentration in circulation at day 24 gestation. Theriogenology, 106: 178-185. DOI:https://10.1016/j.theriogenology.2017.10.020

Restall BJ, Milton JT, Klong-Yutti P and Kochapakdee S (1990). Pregnancy diagnosis in Thai native goats. Theriogenology, 34: $313-$ 137. DOI:https://10.1016/0093-691X(90)90524-W

Santos DJA, Cole JB, Null DJ, Byrem TM and Ma L (2018). Genetic and nongenetic profiling of milk pregnancy-associated glycoproteins in Holstein cattle. Journal of Dairy Science, 101: 9987-10000. DOI:https://10.3168/jds.2018-14682

Shahin M, Friedrich M, Gauly M, Beckers, JF and Holtz W (2013). Pregnancy-associated glycoprotein (PAG) pattern and pregnancy detection in Boer goats using an ELISA with different antisera. Small Ruminant Research, 113:141-144. DOI:https://10.1016/j.smallrumres.2013.01.016

Setiatin ET, Sajuthi D, Purwantara B and Talib C (2009). Extraction and isolation of Ovine Pregnancy-Associated Glycoprotein (ovPAG) from cotyledon placenta of Garut sheep. Journal of Animal and Veterinary Sciences, 14: 208-215. DOI:https://10.14334/jitv.v14i3.342

Singh NS, Gawande PG, Mishra OP, Nema, RK, Mishra UK and Singh M (2004). Accuracy of ultrasonography in early pregnancy diagnosis in Doe. Asian-Australasian Journal of Animal Science, 17: 760-768. DOI:https://10.5713/ajas.2004.760

Singh SP, Natesan R, Sharma N, Goel AN, Singh MK and Kharche SD (2019). Pregnancy-associated glycoprotein profile in milk and its relationship with the circulating level during early pregnancy in goats. Small Ruminant Research, 173: 81-87. DOI:https://10.1016/j.smallrumres.2019.02.017

Sousa NM, Ayad A, Beckers J and Gajewski Z (2006). Pregnancy-associated glycoproteins (PAG) as pregnancy markers in the ruminants. Journal of Physiology and Pharmacology, 8: 153-171. 